\title{
The preserved expression of neuropilin (NRP) 1 contributes to a better prognosis in colon cancer
}

\author{
TAKASHI KAMIYA ${ }^{1}$, TSUTOMU KAWAKAMI ${ }^{1}$, YOSHIYUKI ABE ${ }^{1}$, MASATAKE NISHI $^{1}$, \\ NOBORU ONODA ${ }^{3}$, NORIYUKI MIYAZAKI ${ }^{1}$, YASUHISA OIDA ${ }^{2}$, HITOSHI YAMAZAKI $^{1}$, \\ YOSHITO UEYAMA $^{1,4}$ and MASATO NAKAMURA ${ }^{1,4}$ \\ Departments of ${ }^{1}$ Pathology and ${ }^{2}$ Surgery, Tokai University School of Medicine, Bohseidai, Isehara, Kanagawa 259-1193; \\ ${ }^{3}$ Department of Pathology, Yamato City Hospital, Fukaminisi 8-3-6, Yamato, Kanagawa 242-8602; ${ }^{4}$ Central Institute \\ for Experimental Animals, Nogawa 1430, Kawasaki, Kanagawa 216-0003, Japan
}

Received April 26, 2005; Accepted June 16, 2005

\begin{abstract}
Vascular endothelial growth factor A (VEGF-A) plays an essential role in tumor progression through stromal neovascularization in malignant solid tumors. Neuropilin (NRP) is considered to be the specific receptor for limited types of VEGF-A isoform, VEGF165. The clinicopathological implications of NRP are not well understood in colon cancer, while almost all colon cancers overexpressed VEGF-A. We examined the expression levels of NRP1 and NRP2 genes in 54 colon cancer cases and paired extraneoplastic tissue with quantitative real-time polymerase chain reaction. The gene expression levels of NRP1 in the tumor $(0.431 \pm 0.583)$ were significantly decreased compared to those in the extraneoplastic tissue $(0.754 \pm 0.799)$ (paired t-test, $\mathrm{p}=0.0208)$. On the other hand, the gene expression levels of NRP2 in the tumor $(0.763 \pm 0.791)$ were not decreased compared to those in the extraneoplastic tissue $(0.508 \pm 0.386)$ (paired t-test, $\mathrm{p}=0.0511)$. Twenty cases, with preserved expression of the NRP1 gene in the tumor, showed a better prognosis as compared to the 34 cases with decreased NRP1 expression $(\mathrm{p}=0.0258$, log-rank test). No significant relationship was noted between NRP2 gene expression and prognosis. The results suggested that preserved NRP1 expression provides colon cancer patients with a better prognosis.
\end{abstract}

\section{Introduction}

Angiogenesis is regulated by complicated mechanisms involving various factors (1). Vascular endothelial growth factor A (VEGF-A) is an important angiogenic factor in human solid tumors. Neuropilin (NRP) was known to be an isoform-

Correspondence to: Dr Masato Nakamura, Department of Pathology, Tokai University School of Medicine, Bohseidai, Isehara, Kanagawa 259-1193, Japan

E-mail: mnakamur@is.icc.u-tokai.ac.jp

Key words: neuropilin, colon cancer, prognosis specific receptor for VEGF165 $(2,3)$, while the two best characterized VEGF receptors are termed VEGF receptor 1 (VEGFR1) and VEGF receptor 2 (VEGFR2). NRP was the first discovered neuronal cell guidance receptor of the collapsing/semaphorin family, and is a 130-140 kDa cellsurface glycoprotein. Two subtypes, NRP1 and NRP2, have been isolated and have highly similar structural features (4). They also show differences in their interactions with semaphorins. There is an intimate interplay between NRP1 and NRP2 as neuron guidance factors (4-11). The human NRP1 locus is on chromosome 10 and NRP2 is on chromosome 2 (12).

The detailed mechanism of metastasis is not clearly understood in colon cancer, and some patients with colon cancer die due to systemic metastases even after curative operation. Some have previously reported that NRP was overexpressed in tumor cells of certain cancers, and that the overexpression of NRP was associated with angiogenesis and prognosis in certain cancers (13-16). However, the expression and regulation of NRP in gastrointestinal malignancies, including colon cancer, have not been characterized. The interaction of NRP and VEGF-A is also unknown in colon cancer.

In this study, we examined the gene expression levels of NRP and VEGF-A in surgical specimens (tumor and paired extraneoplastic tissue samples) of colon cancer. We analyzed the relationship between NRP1/NRP2 gene expression and clinical prognosis of patients with colon cancer and we discussed the clinicopathological significance of NRP in colon cancer.

\section{Patients and methods}

Patients. Fifty-four colon cancer specimens were obtained at surgical resection from October 1989 to February 1998 with the patients' informed consent. Tissues were frozen and stored at $-80^{\circ} \mathrm{C}$ until analysis. Total cellular RNA was prepared from the frozen specimens by standard procedure. Surgical specimens were also processed for routine histopathological analysis to estimate the pathological stage. The 54 colon cancer specimens were comprised of 27 moderately differentiated, 
Table I. Gene expression in colon cancer.

\begin{tabular}{lccc}
\hline $\begin{array}{l}\text { Gene } \\
\text { expression }\end{array}$ & Tumor & $\begin{array}{c}\text { Extraneoplastic } \\
\text { tissue }\end{array}$ & $\mathrm{p}$-value \\
\hline NRP1 & $0.431 \pm 0.583$ & $0.754 \pm 0.799$ & $\mathrm{p}=0.0208^{\mathrm{a}}$ \\
NRP2 & $0.763 \pm 0.791$ & $0.508 \pm 0.386$ & $\mathrm{p}=0.0511$ \\
VEGF-A & $0.452 \pm 0.248$ & $0.232 \pm 0.162$ & $\mathrm{p}<0.0001^{\mathrm{a}}$ \\
VEGF165 & $0.161 \pm 0.098$ & $0.093 \pm 0.109$ & $\mathrm{p}=0.0002^{\mathrm{a}}$ \\
\hline
\end{tabular}

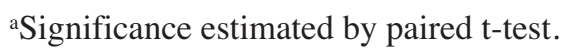

24 well-differentiated and 3 mucinous carcinomas. Corresponding extraneoplastic colon tissue from the same 54 colon cancer patients was also examined. The pathological stages of the colon cancer were as follows: stage I, 6 patients; stage II; 21 patients, stage III; 14 patients and stage IV, 13 patients. The post-surgical treatment observation period was from 15 to 4531 days (1831.6 \pm 1281.1 days).

Gene expression. Total cellular RNA was prepared using an acid guanidinium thiocyanate-phenol-chloroform extraction (AGPC) method. Complementary DNA (cDNA) was synthesized from $1 \mu \mathrm{g}$ of total RNA. Real-time quantitative PCR for NRP1, NRP2, VEGF-A and B-actin mRNA was performed according to the manufacturer's recommendations and our previous reports (17-19). The primers used were as follows: NRP-1 forward AAATGC GAATGGCTGATTCAG, reverse CTCCATCGAAGACTT CCACGTAGT, and probe TCAACCCTCACTTCGATTTG GAGGACA; NRP-2 forward CACCCTCTGAACTTCGTT CATCGACGG, reverse GGATGGCATTCCACATGTTG, and probe TGTGAAAGGTCAGGGAGAGGAT.

We used TaqMan ${ }^{\circledR}$ Universal PCR Master Mix (PE Applied Biosystems, Foster City, CA 94404) for the real-time PCR. For the internal controls, $\beta$-actin-probe-primer mixture for $\beta$-actin mRNA was used (human ACTB, 4310881E, PE Applied Biosystems). Real-time PCR assays were run on an ABI PRISM 7000 Sequence Detection System with the following protocol: after initial denaturation (for $2 \mathrm{~min}$ at $50^{\circ} \mathrm{C}$ and $10 \mathrm{~min}$ at $95^{\circ} \mathrm{C}$ ), amplification was performed with 50 cycles of $15 \mathrm{sec}$ at $95^{\circ} \mathrm{C}$ and $60 \mathrm{sec}$ at $60^{\circ} \mathrm{C}$. All the samples were run in duplicate.

Statistical analysis. The paired t-test and Fisher's exact probability test were applied for comparisons between group frequencies. $\mathrm{p}<0.05$ was considered significant. Differences in survival between subgroups of patients were compared by log-rank test, and survival curves were plotted according to the method of Kaplan-Meier. Data are shown as the mean \pm standard error.

\section{Results}

Gene expression levels of NRP and VEGF-A. We used HCT8 (human colon carcinoma cell line) as the standard. The gene expression levels of NRP1, NRP2, VEGF-A and VEGF165 are summarized in Table I. The gene expression
Table II. Associations between NRP and VEGF-A in colon cancer.

\begin{tabular}{lcrl}
\hline Variable & \multicolumn{2}{c}{ VEGF-A } & p-value \\
\cline { 2 - 3 } & $\geq 0.5(\%)$ & $<0.5(\%)$ & \\
\hline Total & $23(42.6)$ & $31(57.4)$ & \\
NRP1 expression & & & 0.7420 \\
$\quad$ NRP1 $\geq 0.5$ & $6(11.1)$ & $6(11.1)$ & \\
NRP1<0.5 & $17(31.5)$ & $25(46.3)$ & \\
NRP2 expression & & & $0.0275^{a}$ \\
NRP2 $\geq 0.5$ & $6(11.1)$ & $18(33.3)$ & \\
NRP2<0.5 & $17(31.5)$ & $13(24.1)$ & \\
\hline
\end{tabular}

aSignificance estimated by Fisher's exact probability test.

Table III. Associations between NRP and VEGF165 in colon cancer.

\begin{tabular}{lrrr}
\hline Variable & \multicolumn{2}{c}{ VEGF165 } & p-value \\
\cline { 2 - 3 } & $\geq 0.2(\%)$ & $<0.2(\%)$ & \\
\hline Total & $20(37.0)$ & $34(63.0)$ & \\
NRP1 expression & & & 0.1014 \\
NRP1 $\geq 0.5$ & $7(13.0)$ & $5(9.3)$ & \\
NRP1<0.5 & $13(24.1)$ & $29(53.7)$ & \\
NRP2 expression & & & 0.1564 \\
NRP2 $\geq 0.5$ & $6(11.1)$ & $18(33.3)$ & \\
NRP2<0.5 & $14(25.9)$ & $16(29.6)$ & \\
VEGF-A expression & & & $0.0005^{\mathrm{a}}$ \\
VEGF-A $\geq 0.5$ & $15(27.8)$ & $8(14.8)$ & \\
VEGF-A $<0.5$ & $5(9.3)$ & $26(48.1)$ & \\
\hline
\end{tabular}

aSignificance estimated by Fisher's exact probability test.

levels of NRP1 were 0.019-3.313 $(0.431 \pm 0.583)$ in the tumor and $0.008-3.228(0.754 \pm 0.799)$ in the extraneoplastic tissue respectively. The gene expression levels of NRP2 were $0.089-4.882(0.763 \pm 0.791)$ in the tumor and 0.094-1.784 $(0.508 \pm 0.386)$ in the extraneoplastic tissue. The NRP1 gene expression in the tumor was significantly decreased compared with that in the extraneoplastic tissue (paired t-test, $\mathrm{p}=0.0208$ ), and the NRP2 expression gene in the tumor was not decreased compared with that in the extraneoplastic tissue (paired t-test $\mathrm{p}=0.0511$ ). There was no significant relationship between the gene expression of NRP1 and NRP2.

The gene expression levels of VEGF-A were $0.452 \pm 0.248$ in the tumor and $0.232 \pm 0.162$ in the extraneoplastic tissue. The gene expression levels of VEGF165 were $0.161 \pm 0.098$ in the tumor and $0.093 \pm 0.109$ in the extraneoplastic tissue. The expression levels of VEGF-A and VEGF165 genes in 

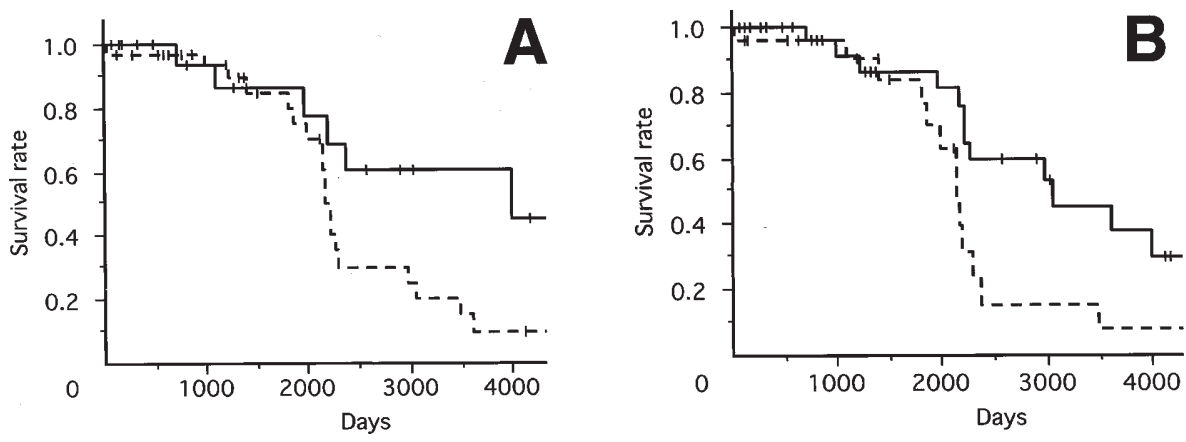

Figure 1. Survival curves of the cases with colon cancer. The colon cancer patients were divided into two groups according to the neuropilin (NRP) gene expression in the cancerous tissue compared to the paired extraneoplastic tissue. A, 20 cases (solid line), with preserved expression of the NRP1 gene in cancerous tissue, showed better prognosis as compared to the 34 cases (broken line) with decreased NRP1 expression ( $\mathrm{p}=0.0258$, log-rank test). B, no significant difference was noted in the prognosis between the group of increased NRP2 expression (solid line, $\mathrm{n}=30$ ) and the others (broken line, $\mathrm{n}=24$ ).

Table IV. Univariate analysis between NRP1 gene expression and clinicopathological features in colon cancer.

\begin{tabular}{|c|c|c|c|}
\hline \multirow[t]{2}{*}{ Variable } & \multicolumn{2}{|c|}{ NRP1 } & \multirow[t]{2}{*}{$\mathrm{p}$-value } \\
\hline & $\geq 0.5(\%)$ & $<0.5(\%)$ & \\
\hline Total & $12(22.2)$ & $42(77.8)$ & \\
\hline $\begin{array}{l}\text { TNM-staging } \\
\text { I } \\
\text { II, III, IV }\end{array}$ & $\begin{aligned} 1 & (1.9) \\
11 & (20.4)\end{aligned}$ & $\begin{aligned} 5 & (9.3) \\
37 & (68.5)\end{aligned}$ & $>0.999$ \\
\hline $\begin{array}{l}\text { T factor } \\
\mathrm{T} 1, \mathrm{~T} 2 \\
\mathrm{~T} 3, \mathrm{~T} 4\end{array}$ & $\begin{aligned} 1 & (1.9) \\
11 & (20.4)\end{aligned}$ & $\begin{array}{r}6(11.1) \\
36(66.7)\end{array}$ & $>0.999$ \\
\hline $\begin{array}{l}\mathrm{N} \text { factor } \\
\text { N0 } \\
\mathrm{N} 1, \mathrm{~N} 2\end{array}$ & $\begin{array}{ll}5 & (9.3) \\
7 & (13.0)\end{array}$ & $\begin{array}{ll}24 & (44.4) \\
18 & (33.3)\end{array}$ & 0.513 \\
\hline $\begin{array}{l}\text { Metastasis } \\
\text { M0 } \\
\text { M1 }\end{array}$ & $\begin{array}{ll}8 & (14.8) \\
4 & (7.4)\end{array}$ & $\begin{array}{r}33(61.1) \\
9(16.7)\end{array}$ & 0.453 \\
\hline $\begin{array}{l}\text { ly factor } \\
\text { ly0 } \\
\text { ly } 1-3\end{array}$ & $\begin{aligned} 2 & (3.7) \\
10 & (18.5)\end{aligned}$ & $\begin{array}{ll}11 & (20.4) \\
31 & (57.4)\end{array}$ & 0.708 \\
\hline $\begin{array}{l}\text { v factor } \\
\text { v0 } \\
\text { v1-3 }\end{array}$ & $\begin{aligned} 1 & (1.9) \\
11 & (20.4)\end{aligned}$ & $\begin{array}{r}7(13.0) \\
35(64.8)\end{array}$ & 0.667 \\
\hline
\end{tabular}

the tumor were significantly higher than those in the paired extraneoplastic tissue (paired t-test, $\mathrm{p}<0.0001$ and $\mathrm{p}=0.0002$ respectively). The gene expression of NRP2 was correlated with VEGF-A ( $\mathrm{p}=0.0275$ Fisher's exact probability test), while no significant relationship was noted between the gene expression of NRP1 and VEGF-A or VEGF165 (Tables II and III).

Clinical implications of NRP expression. We evaluated the NRP gene expression in cancerous tissue as compared to extraneoplastic tissue. Twenty cases showed a higher expression level of the NRP1 gene in the cancerous tissue than in the extraneoplastic tissue, including 6 remarkably overexpressing cases (more than 5 times the expression in the cancerous tissue). The other 34 cases showed decreased expression of the NRP1 gene in the cancerous tissue compared with the extraneoplastic tissue, including 5 severely decreased cases (less than one-tenth the expression in the cancerous tissue). The 20 cases with higher NRP1 gene expression significantly revealed a better prognosis than the other 34 cases ( $\mathrm{p}=0.0258, \log$-rank test, Fig. 1A).

Thirty cases showed a higher expression level of the NRP2 gene in the cancerous tissue compared with the extraneoplastic tissue, including 6 severely increased cases (more than 5 times the expression in the cancerous tissue). The other 24 cases showed a decreased expression of the NRP2 gene, including 1 severely decreased cases (less than one-tenth the expression in the cancerous tissue). There was no significant relationship between the NRP2 expression and prognosis (Fig. 1B).

The relationship between NRP1 gene expression and the other clinicopathological features in colon cancer are summarized in Table IV. There was no significant relationship between NRP1 expression and the other factors.

\section{Discussion}

We examined the expression levels of NRP1 and NRP2 genes in 54 colonic cancer cases (tumor and paired extraneoplastic tissue) by quantitative real-time PCR. The NRP1 gene expression in cancerous tissue decreased significantly compared with paired extraneoplastic tissue, while the NRP2 gene expression was not decreased in cancerous tissue. The cases with preserved NRP1 expression showed significantly better prognoses than the others, while no significant relationship was noted between NRP2 gene expression and prognosis. The results suggest that preserved NRP1 expression provides colonic cancer patients with better prognoses.

NRP1 was co-receptor for VEGF165 and was expressed in several types of cancerous cells, such as breast and prostate cancer cells (2). We and others previously reported that NRP overexpression in cancer was associated with angiogenesis and poor prognosis in patients with osteosarcoma, non-small-cell 
lung cancer, glioblastoma and prostate carcinoma (13-16). However, this study showed that preserved NRP1 expression provides colon cancer patients with better prognoses.

Parikh et al reported that NRP1 was expressed in all 20 human colon adenocarcinoma specimens but not in extraneoplastic tissue using immunohistochemistry and in situ hybridization with frozen sections (26). They did not examine the expression of NRP1 mRNA in the specimens of colon cancer and normal colonic mucosa, while they showed that NRP1 mRNA was expressed in colon adenocarcinoma cell lines by reverse transcriptase-PCR assay. We demonstrated that NRP1 expression was decreased in the tumor compared to the paired extraneoplastic tissue in colon cancer, and that NRP2 expression was not decreased in the tumor using realtime PCR.

In this study, the gene expression of NRP2 was correlated with VEGF-A, while no significant relationship was noted between NRP2 expression and prognosis. Previously, we reported that VEGF189 is closely related to liver metastasis and prognosis in colon cancer (27). Akagi et al reported that activation of the epidermal growth factor receptor may contribute to gastric cancer angiogenesis by a mechanism that involves the upregulation of VEGF-A and NRP1 expression via multiple signaling pathways (28). However, they also reported that VEGF165 had no effect on cell growth in NRP1-positive gastric cancer cell lines. These results suggest that VEGF165 is not a key factor for angiogenesis in gastrointestinal cancer such as colon cancer and gastric cancer.

Inhibitors of VEGF-A may have an impact on the growth and metastasis of colon cancer. One of the most effective ways to block the VEGF-signaling pathway is known to prevent VEGF-A from binding to its normal receptors by administering decoy-soluble receptors (20-22). The relevance of this strategy to the treatment of colorectal cancer was first successfully demonstrated in human clinical trials using a monoclonal antibody against VEGF-A $(23,24)$. A potent antiangiogenic soluble recombinant decoy, VEGF Trap, is a protein constructed from VEGF receptor-binding domains linked to an immunoglobulin G constant region (22). VEGF Trap has demonstrated a marked efficacy in halting angiogenesis and shrinking tumors in preclinical animal models and is currently being studied in phase I clinical trials in humans with advanced solid malignancies (25). In this study, the patients with colon cancer preserving NRP1 expression showed better prognoses. The results suggest the possible neutralizing activity of NRP1 as the decoy receptor for VEGF-A. In conclusion, the preserved expression of NRP1 might contribute to better prognoses in colonic cancer via its function as a decoy receptor.

\section{Acknowledgements}

This work was supported in part by Grants-in-Aid for Cancer and Scientific Research from the Ministry of Education, Science and Culture of Japan (M.N. 16590325 and Y.U. 16300137). We thank Mr. Yuichi Tada and Dr Johbu Itoh for their technical assistance.

\section{References}

1. Risau W: Mechanisms of angiogenesis. Nature 386: 671-674, 1997.
2. Soker S, Takashima S, Miao HQ, Neufeld G and Klagsbrun M: Neuropilin-1 is expressed by endothelial and tumor cells as an isoform-specific receptor for vascular endothelial growth factor. Cell 92: 735-745, 1998.

3. Whitaker GB, Limberg BJ and Rosenbaum JS: Vascular endothelial growth factor receptor-2 and neuropilin-1 form a receptor complex that is responsible for the differential signaling potency of VEGF(165) and VEGF(121). J Biol Chem 276: 25520-25531, 2001.

4. Chen H, Chedotal A, He Z, Goodman CS and Tessier-Lavigne M: Neuropilin-2, a novel member of the neuropilin family, is a high affinity receptor for the semaphorins Sema E and Sema IV but not Sema III. Neuron 19: 547-559, 1997.

5. He Z and Tessier-Lavigne M: Neuropilin is a receptor for the axonal chemorepellent Semaphorin III. Cell 90: 739-751, 1997.

6. Kolodkin AL, Levengood DV, Rowe EG, Tai YT, Giger RJ and Ginty DD: Neuropilin is a semaphorin III receptor. Cell 90: 753-762, 1997.

7. Kawakami A, Kitsukawa T, Takagi S and Fujisawa $\mathrm{H}$ : Developmentally regulated expression of a cell surface protein, neuropilin, in the mouse nervous system. J Neurobiol 29: 1-17, 1996.

8. Takagi S, Kasuya Y, Shimizu M, et al: Expression of a cell adhesion molecule, neuropilin, in the developing chick nervous system. Dev Biol 170: 207-222, 1995.

9. Chen H, Chedotal A, He Z, Goodman CS and Tessier-Lavigne M: Neuropilin-2, a novel member of the neuropilin family, is a high affinity receptor for the semaphorins Sema E and Sema IV but not Sema III. Neuron 19: 547-559, 1997

10. Takahashi T, Namura F, Jin Z, Kalb RG and Strittmatter SM: Semaphorins $\mathrm{A}$ and $\mathrm{E}$ act as antagonists of neuropilin-1 and agonists of neuropilin-2 receptors. Nat Neurosci 1: 487-493, 1998.

11. Giger RJ, Urquhart ER, Gillespie SK, Levengood DV, Ginty DD and Kolodkin AL: Neuropilin-2 is a receptor for semaphorin IV: insight into the structural basis of receptor function and specificity. Neuron 21: 1079-1092, 1998.

12. Rossignol M, Beggs AH, Pierce EA and Klagsbrun M: Human neuropilin-1 and neuropilin-2 map to $10 \mathrm{p} 12$ and 2q34, respectively. Genomics 57: 459-460, 1999.

13. Miao HQ, Lee P, Lin H, Soker S and Klagsbrun M: Neuropilin1 expression by tumor cells promotes tumor angiogenesis and progression. FASEB J 14: 2532-2539, 2000.

14. Handa A, Tokunaga T, Tsuchida T, et al: Neuropilin-2 expression affects the increased vascularization and is a prognostic factor in osteosarcoma. Int J Oncol 17: 291-295, 2000.

15. Kawakami T, Tokunaga T, Hatanaka H, et al: Neuropilin 1 and neuropilin 2 co-expression is significantly correlated with increased vascularity and poor prognosis in nonsmall cell lung carcinoma. Cancer 95: 2196-2201, 2002.

16. Osada H, Tokunaga T, Nishi M, et al: Overexpression of the neuropilin 1 (NRP1) gene correlated with poor prognosis in human glioma. Anticancer Res 24: 547-552, 2004.

17. Fujimori S, Abe Y, Nishi M, et al: The subunits of glutamate cysteine ligase (GCL) enhance cisplatin resistance in human nonsmall cell lung cancer xenografts in vivo. Int J Oncol 25: 413-418, 2004.

18. Hamamoto A, Abe Y, Nishi M, et al: Aberrant expression of the gastric mucin MUC6 in human pulmonary adenocarcinoma xenografts. Int J Oncol 26: 891-896, 2005.

19. Nishi M, Abe Y, Tomii Y, et al: Cell binding isoforms of vascular endothelial growth factor-A (VEGF189) contribute to blood flow-distant metastasis of pulmonary adenocarcinoma. Int J Oncol 26: 1517-1524, 2005.

20. Ferrara N, Chen H, Davis-Smyth T, et al: Vascular endothelial growth factor is essential for corpus luteum angiogenesis. Nat Med 4: 336-340, 1998.

21. Gerber HP, Kowalski J, Sherman D, Eberhard DA and Ferrara N: Complete inhibition of rhabdomyosarcoma xenograft growth and neovascularization requires blockade of both tumor and host vascular endothelial growth factor. Cancer Res 60: 6253-6258, 2000.

22. Holash J, Davis S, Papadopoulos N, et al: VEGF-Trap: a VEGF blocker with potent antitumor effects. Proc Natl Acad Sci USA 99: 11393-11398, 2002.

23. Shaheen RM, Ahmad SA, Liu W, et al: Inhibited growth of colon cancer carcinomatosis by antibodies to vascular endothelial and epidermal growth factor receptors. Br J Cancer 85: 584-589, 2001 . 
24. Iqbal S and Lenz HJ: Angiogenesis inhibitors in the treatment of colorectal cancer. Semin Oncol 31 (suppl 17): 10-16, 2004.

25. Byrne AT, Ross L, Holash J, et al: Vascular endothelial growth factor-trap decreases tumor burden, inhibits ascites, and causes dramatic vascular remodeling in an ovarian cancer model. Clin Cancer Res 9: 5721-5728, 2003.

26. Parikh AA, Liu WB, Fan F, et al: Expression and regulation of the novel vascular endothelial growth factor receptor neuropilin-1 by epidermal growth factor in human pancreatic carcinoma. Cancer 98: 720-729, 2003.

27. Tokunaga T, Oshika Y, Abe Y, et al: Vascular endothelial growth factor (VEGF) mRNA isoform expression pattern is correlated with liver metastasis and poor prognosis in colon cancer. Br J Cancer 77: 998-1002, 1998.

28. Akagi M, Kawaguchi M, Liu W, et al: Induction of neuropilin-1 and vascular endothelial growth factor by epidermal growth factor in human gastric cancer cells. Br J Cancer 88: 796-802, 2003. 